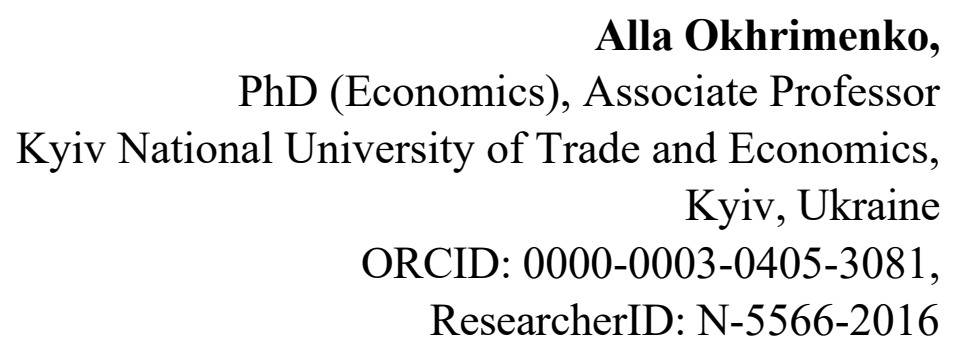

Alla Domyshche-Medyanyk,

$\mathrm{PhD}$ (Economics), Associate Professor

Uzhhorod Institute of Trade and Economics of Kyiv National University of

Trade and Economics, Uzhhorod, Ukraine ORCID: 0000-0002-1240-8797, ResearcherID: AAH-4631-2020

Kateryna Bogatyrova, $\mathrm{PhD}$ (Philology), Associate Professor, Kyiv National University of Trade and Economics, Kyiv, Ukraine ORCID: 0000-0003-4749-1137

ResearcherID: N-1707-2016

\title{
PARADIGM OF THE NATIONAL TOURIST SYSTEM
}

The importance and necessity of understanding the paradigm of the national tourist system, which reflects its initial concept and basic principles, is revealed. The article summarizes the authors' vision for the formation of this paradigm. It is justified that the formation of the paradigm of the national tourism system is carried out on the basis of the cohesion of the paradigms of economic and tourism systems. The authors understand the paradigm of the national tourism system as a polystructural, integrated, network, creative formation that is developing in the conditions of transitivity, digitazation, experience economy, blurring the lines between tourism and everyday life, on the principles of sustainable development, inclusivity and globalization. It contributes to the formation of social, ecological and economic result, humanization and person-oriented approach in the society.

Key words: paradigm, tourism, national tourism system

Relevance of the topic. The national tourist system combines a significant number of economic activities, resources, institutional structures, information and communication channels within its functioning and it is also a prerequisite for the development of hotel, restaurant, transport, insurance and other services. Therefore, it is necessary to understand the system of concepts for this important sphere, which describes the features of the phenomena and processes inherent in the national tourism system, to understand its initial 
concept and basic principles. These principles form the basic requirements on which the national tourism system is researched and reflect its paradigm.

Statement of the issue. The current stage of development of tourism systems is characterized by a variety of approaches, theories, visions, so the understanding of the paradigm for any complex system, including the tourist system, is extremely important and necessary. The study is based on this idea and it identifies the fundamental principles of the paradigm of the national tourism system.

The analysis of recent researches and publications. Many scholars naturally link the development of tourism systems to the dominant worldview paradigm in their studies. Thus, P. M. Burns and M. Novelli in their work (2006, p. 7) emphasize that «in-groups and out-groups, social identity, nationalism, ethnocentrism, postmodernism, culture, etc. have great resonance for tourism studies on both sides of the «host - guest» equation (or with increased mobility perhaps we should call it a continuum)». T. Kuhn was the first who used the concept of paradigm in science in the second half of the twentieth century. He defined paradigm as «universally recognized scientific achievements that, for a time, provide model problems and solutions for a community of researchers».

Nowadays, in the late twentieth - early twenty-first centuries, tourism is characterized by very dynamic and comprehensive scales. A lot of researches have been devoted to determining the forces, scales and consequences of the transformation of tourism systems. However, it is quite difficult to identify clearly the defining features, essence and duration of the modern tourism development period. Thus, J. Tribe, G. Dann and T. Jamal $(2015$, p. 1$)$ in their study emphasize that «tourism research is not governed by restrictive paradigms on the spatial level, but the social level of neoliberalism may limit paradigms».

Although tourism had deep historical roots, however, it was formed as the object of scientific researches in the second half of the twentieth century (Airey, 2007; Jafari, 2007; Nash, 2007). Thus, Airey D., Tribe J. (2007) highlight in their works industrial, fragmentary, benchmarking and maturity stages of tourism science. E. Fayos-Sola $(1996,2013)$ uses different approach to interpreting the periodization of the development and study of tourism systems in the late twentieth - early twenty-first centuries. He distinguishes «The Fordian Tourism» (the paradigm of mass tourism) and the paradigm of «ThePost-FordianTourism» («post-mass», «individual» tourism) in his works. According to this interpretation, the period of «mass tourism» is referred to as «The Fordian Tourism» or «The Fordianphase» (from 1960 to 1970), when signs of a global phenomenon began to emerge in tourism, the supply of services was standardized, transportation, especially aviation, was developed rapidly. Thus, we state the diversity of opinions on the periodization and paradigms of tourism systems.

The overview of the main research material. In this study we assume that the evolution of the national tourist system is based on the synthesis of development on the one hand - economic systems and on the other hand - tourism systems. The following paradigms of economic systems are historically distinguished: classical, neoclassical, institutional, Keynesian, neoinstitutionalism, monetarism, systemic, evolutionary, 
neoliberalism, postneoclassical, postmodern, non-systemic, post-industrial paradigms. Tourism is characterized by a variety of views, in particular «since the nineteenth century there has been a large-scale transition from a more or less unified tourist understanding to the spread of innumerable discourses, forms and embodiments of tourist views, so in a simple sense we can speak of the globalization of the tourist view, because multiple thoughts are the basis of a global culture that is developing almost everywhere» (Urry 2001, p. 7). This confirms the existence in tourism of different full-fledged paradigms and sub-paradigms, and we believe that they correspond exactly to the different stages of its development that need to be considered.

The scientific systematization of views on tourism, with a clear identification of paradigms (platforms), concerns a fairly recent period, dating from the 1960's. This opinion was supported by the fact that the consideration of tourism as a systemic phenomenon began in the 1960's. Internationally recognized scientist J. Jafari (2003) identifies 5 platforms (periods) of change in the tourism research system. We understand these platforms as «paradigms». In addition, from the point of view of the present, let us try to make some additions to these paradigms (Table 1).

Table 1

\section{Dynamics of change (platforms / paradigms) in the tourism researches system}

\begin{tabular}{|c|c|c|c|}
\hline $\begin{array}{c}\text { Platform / } \\
\text { period }\end{array}$ & Name of phase (platform) & $\begin{array}{l}\text { The main features of the phase } \\
\text { (platform) }\end{array}$ & $\begin{array}{c}\text { Authors' } \\
\text { selection of paradigms }\end{array}$ \\
\hline $1 /$ the $1960 \mathrm{~s}$ & The advocacy platform & $\begin{array}{l}\text { Domination of economic views on } \\
\text { tourism }\end{array}$ & $\begin{array}{l}\text { The economic } \\
\text { paradigm of tourism }\end{array}$ \\
\hline $2 /$ the 1970 s & The cautionary platform & $\begin{array}{l}\text { Identification of negative and } \\
\text { positive impacts of tourism, } \\
\text { especially in the context of ecology }\end{array}$ & $\begin{array}{l}\text { Ecological paradigm } \\
\text { of sustainable tourism } \\
\text { development }\end{array}$ \\
\hline $3 /$ the $1980 s$ & The adaptancy platform & $\begin{array}{l}\text { The emergence of alternatives to } \\
\text { mass tourism }\end{array}$ & \multirow[t]{2}{*}{$\begin{array}{c}\text { Socio-cultural } \\
\text { paradigm of tourism }\end{array}$} \\
\hline $4 /$ the $1990 s$ & The knowledge platform & $\begin{array}{l}\text { More comprehensive (complete) } \\
\text { understanding of tourism as an } \\
\text { interdisciplinary phenomenon }\end{array}$ & \\
\hline 5 /from 2005 & The publicoutreachplatform & $\begin{array}{l}\text { Positioning of tourism in global } \\
\text { political structures, attracting a } \\
\text { wider range of stakeholders }\end{array}$ & $\begin{array}{l}\text { Integrative paradigm } \\
\text { of tourism }\end{array}$ \\
\hline $6 /$ from 2010 & no information & $\begin{array}{l}\text { Blurring the lines between tourism } \\
\text { and other activities; technological } \\
\text { innovations; development of } \\
\text { human potential by means of } \\
\text { tourism }\end{array}$ & $\begin{array}{c}\text { Paradigm of } \\
\text { mobility, transience } \\
\text { and creativity of } \\
\text { tourism }\end{array}$ \\
\hline
\end{tabular}

Source: Revised by the authors by Jafari, J. (2003)

Thus, we note that over time, under the influence of socio-economic, political, technological, psychological and mental factors, there is a «transition from the paradigm of «mass tourism», which has been the norm for over thirty years (since its capacity is not enough to achieve competitiveness) to a new paradigm or «new tourism» that is gaining ground due to its ability to cope with prevailing circumstances» (Fayos-Sola, 1996). The International Conference on Innovation in 
Tourism and Hospitality (CIT 2013, Valencia, Spain) was held under the theme: «tourism has offered worship to the 'Ford' archetype of mass production and mass consumption for too long. «It is time to change the paradigm» (Fayos-Sola, 2013). ThePost-FordianTourism is characterized by the processes of marketing expansion, new forms of production, public-private partnerships and reduction of state interference.

Such view expresses D. Dredge (2016): «tourism and hospitality are now showing signs of moving into a post-industrial epoch. In this new order, the tourism industry is moving away from a Fordist industrial model of production and consumption; it is de-industrialising and its traditional structures (supply chains, management structures, etc.) are breaking down and reconfiguring» (Dredge, 2016, p. 20).

We have analysed the overview based on the past and present of tourism systems and believe that the following major priorities for their development can be outlined: 1) continue the implementation of sustainable development ideas; 2) creativity in different spheres, actions, social networks; 3) mobility and rapidity of tourism; 4) deepening globalization; 6) dominance of digital technologies and their further improvement; 7) cooperation and implementation of the idea of a reflexive approach to tourism; 8 ) network cooperation in the management of tourism systems (state-private-public); 9) dissemination of the «informal component» (provision of tourist services, organized in the freelance form, tourism of public organizations, amateur tourism) and processes of «shared consumption»; 10) «blurring», the destruction of borders, boundaries and other obstacles to travel and the involvement of more and more people in these processes; 11) search for personal identity through tourism; 12) understanding the dynamics and rapidity of processes; 13) need for travel, as in ordinary household activities; 14) blurring the borders and reducing the difference in culture and everyday life; 15) enrichment, development, experience, satisfaction; 16) pursuit of authenticity; 17) creative tourism; 18) overtourism; 19) responsible tourism.

Conclusions. Comparative analysis of the evolution of the development of paradigms of economic systems and tourism systems confirm the natural interconnection of these processes: 1) on the one hand, the prerequisite for the formation of the paradigm of the national tourism system is its study as an economic system; 2) on the other hand, the NTS paradigm is based on the study of tourism systems. The identification of the paradigms of tourism systems, despite the fact that the paradigm is a coherent and stable set of views shared by a scientific society over a long period, testifies the diversity of views and interpretations. This confirms again that the study of tourism systems is in the initial stages and the research requires the construction of a stable and integrated platform.

It should also be noted that in the current «fleeting» reality of the paradigm cannot be considered too rigid and immutable, on the contrary, they become flexible and variable and they are characterized by the multiple of variants of their understanding, as well as the possibility of modifications of the structure under the influence of changing environmental parameters. Therefore, the NTS paradigm is 
formed taking into account the optimal and mutually agreed combination of these paradigms of economic and tourism systems with the application of the principles of sustainable development, adaptability, taking into account the changing endogenous and exogenous factors. Accordingly, the NTS paradigm is seen as poly-structural, integrated, network, creative entity that develops in the conditions of transitivity, digitazation, experience economy, blurring the lines on the principles of sustainable development, inclusivity, globalization, and it contributes to the formation of ecological, social and economic development and humanization of the society.

\section{REFERENCES}

1. Airey D. (2015). 40 years of tourism studies - a remarkable story. Tourism Recreation Research.40(1). - P. 6-15 Retrieved from DOI: $10.1080 / 02508281.2015 .1007633$

2. Burns P.M., Novelli M. (2006). Tourism and social identities. Global frameworks and local realities. Langford Lane, Kidlington, Oxford, UK, Amsterdam, The Netherlands. $221 \mathrm{p}$.

3. Dredge D. (2016). Of things to come: Tourism and hospitality education in a post-industrial age. The Business of Tourism. Vol.17. P. 19-23.

4. Fayos-Sola E. (1996). Tourism Policy: A midsummer night's dream? Tourism Management. Vol. 17(6). P. 405-412.

5. Fayos-Sola E. (2013). The Need for Innovation in Tourism Destination Governance. Papers de turisme. Vol. 54. P. 11-13.

6. Jafari J. (2003). Research and scholarship: the basis of tourism education. Journal of Tourism Studies. Vol. 14 (1). P. 6-16.

7. Kuhn T. (1962). The structure of scientific revolutions. Chicago: University of Chicago Press, 1962.

8. Mazaraki A., Boiko M., Bosovska M., Vedmid N., Okhrimenko A. (2018). Formation of National Tourism System of Ukraine. Problems and Perspectives in Management. Vol. 16 (1). P. 68-84 Retrieved from http://dx.doi.org/10.21511/ ppm.16(1).2018.07

9. Nash D. (2007). The study of tourism: Anthropological and sociological beginnings. Oxford: Elsevier. T. 9.

10. Okhrimenko, A. H. (2019), Natsional'na turystychna systema [National tourismsystem], Kyivs'kyj natsional'nyj torhovel'no-ekonomichnyj universytet, Kyiv, Ukraine. [in Ukrainian].

11. Tribe J., Dann G., Jamal T. (2015). Paradigms in Tourism Research: A Trialogue. Tourism recreation research. Vol. 40 Retrieved from doi/full/10.1080/02508281.2015.1008856? src=recsys

12. Urry J. (2001). The Tourist Gaze. 2-nd ed. London: Sage. 